\title{
Notochord induction of zebrafish slow muscle mediated by Sonic hedgehog
}

\author{
Chris S. Blagden, ${ }^{1,3}$ Peter D. Currie, 2,3 Philip W. Ingham, ${ }^{2,4}$ and Simon M. Hughes ${ }^{1,5}$ \\ ${ }^{1}$ Developmental Biology Research Centre and Medical Research Council (MRC) Muscle and Cell Motility Unit, The Randall \\ Institute, King's College London, London WC2B 5RL, UK; ${ }^{2} \mathrm{M}$ olecular Embryology Laboratory, Imperial Cancer Research \\ Fund, London WC2A 3PX, UK
}

\begin{abstract}
The patterning of vertebrate somitic muscle is regulated by signals from neighboring tissues. We examined the generation of slow and fast muscle in zebrafish embryos and show that Sonic hedgehog (Shh) secreted from the notochord can induce slow muscle from medial cells of the somite. Slow muscle derives from medial adaxial myoblasts that differentiate early, wherees fast muscle arises later from a separate myoblast pool. Mutant fish lacking shh expression fail to form slow muscle but do form fast muscle. Ectopic expression of shh, either in wild-type or mutant embryos, leads to ectopic slow muscle at the expense of fast. We suggest that Shh acts to induce myoblasts committed to slow muscle differentiation from uncommitted presomitic mesoderm.
\end{abstract}

[Key Words: Zebrafish; muscle; fiber type; adaxial cells; sonic hedgehog; myoblast]

Received April 3, 1997; revised version accepted July 4, 1997.

All vertebrates have two classes of muscle fibers: slow and fast. Sl ow fibers have low-force, long-duration contractions because they express myosin isoforms that are specialized for slow contraction and an oxidative metabolism. Fast fibers have distinct fast myosins and glycolytic metabolism, ideal for high-force, short-duration contractions. Each muscle has a specific mix and spatial array of fast and slow fibers from its formation early in development. How such arrays are patterned is unknown, but evidence for two contrasting models exists. In one view, proliferative myoblasts are intrinsically committed to form either fast or slow fibers and accumulate in appropriate regions of the embryo. Clonal cell analysis in chicks shows that myoblasts are heterogeneous before their differentiation: Some are specialized to form slow muscle, whereas others form fast (Miller and Stockdale 1986; Schafer et al. 1987; DiM ario et al. 1993). Alternatively, naive myoblasts could be instructed by their environment to express specific isoforms of muscle proteins at the time of differentiation, as occurs in postnatal rodent muscles (Hughes and Blau 1992). A resolution of this issue is suggested by studies in Drosophila where local extrinsic signals induce commitment of muscle founder myoblasts to the formation of a particular type of muscle in each location (Baylies et al. 1995). In this paper, we examine vertebrate muscle patterning in the zebrafish somite. We show that the

\footnotetext{
${ }^{3}$ The first two authors have contributed equally to this work. 4Present address: Developmental Genetics Programme, The Krebs Institute, University of Sheffield, Sheffield S10 2TN, UK. ${ }^{5}$ Corresponding author.

E-MAIL s.hughes@kcl.ac.uk; FAX 44-171 4979078.
}

secreted glycoprotein Sonic hedgehog (Shh) regulates the decision between fast and slow muscle formation and we suggest this decision involves induction of a specifically slow myoblast type.

Muscles are formed by the differentiation of mononucleate proliferative myoblasts into post-mitotic myocytes that subsequently fuse to form multinucleate muscle fibers. In amni otes, muscle fi bers differentiate in two waves: The first-formed primary fibers are generally slow, whereas later secondary fibers, which form in close association with primary fibers, are fast (Kelly and Rubinstein 1980). These two fiber types are not separated spatially and, as they are formed over a considerable time period, the fate of individual cells as they mature has not been followed. In zebrafish, by contrast, somitic muscle fi bers form in two temporally separated waves. The early differentiating cells are formed medially near the notochord and migrate laterally during late somitogenesis to become slow muscle (van Raamsdonk et al. 1978; De voto et al. 1996). However, most somitic cells differentiate later and become fast muscle. How spatial information in the early somite generates this pattern is unclear.

The differentiation of somites is central to vertebrate mesoderm development. Somites are epithelial balls of mesoderm that arise from a mesenchymal mass of proliferative paraxial tissue in a rostro-caudal order. Once formed, somites differentiate rapidly into a ventral sclerotomal mesenchymal compartment and a dorsal epithelial structure, the dermomyotome. In lower vertebrates, such as fish, in which the sclerotome is small (Morin-Kensicki and Eisen 1997), the somite mainly gives rise to muscle. In amniotes, the dermomyotome contributes to trunk dermis and to several distinct popu- 
Iations of muscle cells. The dorsomedial lip of the dermomyotome, which is located next to the neural tube, forms differentiated muscle of the myotome that arises between the sclerotome and dermomyotome.

Signals from adjacent tissues regulate somitic muscle differentiation (for review, see Lassar and M unsterberg 1996). However, the precise source, nature, and roles of these signals is unclear. Axial structures (neural tube and notochord) are important as their removal leads to cell death and somite regression (Teillet and Le Douarin 1983; Rong et al. 1992), and they can enhance both myogenesis and chondrogenesis (Kenny-Mobbs and Thorogood 1987). N otochord can induce myogenesis in some assays of myogenic induction (Buffinger and Stockdale 1995; Gamel et al. 1995; Stern et al. 1995; Pownall et al. 1996), although ectopically positioned notochords in chick embryos can induce sclerotome at the expense of myogenic tissue (Pourquie et al. 1993; Bober et al. 1994; Fan and Tessi er-Lavigne 1994; Goulding et al . 1994). Shh is a signaling molecule expressed in notochord at times when this tissue can influence muscle differentiation (Echelard et al. 1993; Krauss et al. 1993; Johnson et al. 1994; Roelink et al. 1994; Marti et al 1995). Shh can substitute for notochord in various assays of both sclerotome and muscle induction (Fan et al . 1995; M unsterberg et al. 1995), and induce ectopic muscle markers in vivo Johnson et al. 1994; Concordet et al. 1996; Hammerschmidt et al. 1996; Weinberg et al. 1996). Moreover, mice homozygous for a targeted deletion of the shh gene have deficits in sclerotome and myotome precursor cell markers (Chiang et al . 1996). These data suggest that Shh may mediate notochord-dependent signals that induce myogenesis. However, two lines of evidence argue against this simple view. First, both the $M y o D$ and Myf-5 muscle-specific transcription factors are still expressed in shh ${ }^{-1}$ mouse somites, although Myf-5 mRN A is reduced (Chiang et al. 1996). As Myf-5 and MyoD are myoblast markers in amniotes, this suggests that the myogenic program can be initiated in the absence of Shh. Second, ablation of all axial structures has little effect on limb and body wall muscle development although somitic myogenesis is reduced, partly attributable to regression of the somite (Rong et al. 1992). Therefore, although notochord-derived Shh is a strong candidate for a regulator of myotomal muscle formation, its precise role in myogenesis remains enigmatic.

A confounding factor in understanding myotomal muscle induction is the heterogeneity of myogenic cell populations within the somite (for review, see Cossu et al. 1996b). The phenotypes of mice with null mutations in members of the M yoD family of myogenic regulatory transcription factors (M RFs) suggest that several distinct populations of myogenic cells exist in different parts of the developing murine dermomyotome (Rudnicki et al. 1993; Tajbakhsh et al. 1997) and these populations appear to differ in their sensitivity to loss of Shh (Chiang et al. 1996). In addition to notochord, neural tube al so contains inductive signal s that can support somitic myogenesis (Teillet and Le Douarin 1983; Rong et al. 1992; Goulding et al. 1994; Buffinger and Stockdale 1995; Stern and Hauschka 1995), and dorsal neural tube can induce myogenesis, an effect that can be mimicked by some Wnt proteins (Gamel et al. 1995; Munsterberg et al. 1995; Stern et al. 1995). Moreover, inhibitory signals from lateral plate mesoderm and surface ectoderm have been suggested to influence myogenesis (Fan and Tessier-Lavigne 1994; Pourquie et al. 1996). Therefore, although several distinct signals and muscle cell populations exist, what signal s induce each cell population in vivo is unclear.

In the zebrafish, the somite gives rise mainly to muscle, which is probably the primary fate of paraxial mesoderm during early chordate evolution (Holland et al. 1995). Even in this simple system, however, three muscle cell populations can be resolved. Adaxial cells form next to the notochord, eventually giving rise to slow muscle (van Raamsdonk et al. 1978; Devoto et al. 1996) and are the first cells in the embryo to express the muscle transcription factors myoD and mef2D, mef2A, and mef2C (Ticho et al. 1996; Weinberg et al. 1996). A specialized subpopulation of adaxial cells, the muscle pioneers, form at the dorsoventral midline of each somite (Felsenfeld et al. 1991), express engrailed proteins (Hatta et al. 1991), and appear to be induced by two sequential signals from outsi de the somite (Currie and Ingham 1996). The majority of the somite forms the third muscle cell population that both expresses myoD and differentiates later (Devoto et al. 1996; Weinberg et al. 1996).

Here, we describe the development of slow and fast muscle in the zebrafish embryo. We show that, as in amniotes, slow muscle differentiates first and that fast muscle is formed later in close association with differentiated slow fibers. We demonstrate that notochord-derived signals are required for formation of slow, but not fast, muscle. We find that Shh, a molecule expressed and secreted by early notochord, can induce slow muscle ectopically at the expense of fast muscle. Taken together, our results suggest that slow primary muscle in zebrafish somites is induced by Shh from the notochord, but that neither notochord nor primary slow muscle is required to control the timing of secondary fast fiber differentiation.

\section{Results}

Early zebrafish embryos have distinct fast and slow muscle cell populations

To examine the patterning of muscle in zebrafish somites, we screened a series of anti-M yHC monoclonal antibodies for reactivity with 1- to 2-day zebrafish muscle tissue. Two antibodies detected all differentiated skel etal and heart muscle, whereas three antibodies detected specific subpopulations of cells within the somites of 24-hr (prim-5) embryos (Fig. 1). BA-D5, an antibody that specifically detects slow $\mathrm{M}$ yHC in muscle fi bers of all ages of mammals and chicks examined (Schiaffino et al. 1989; C.S. Blagden and S.M. Hughes, unpubl.), detects a single layer of cells in the superficial 

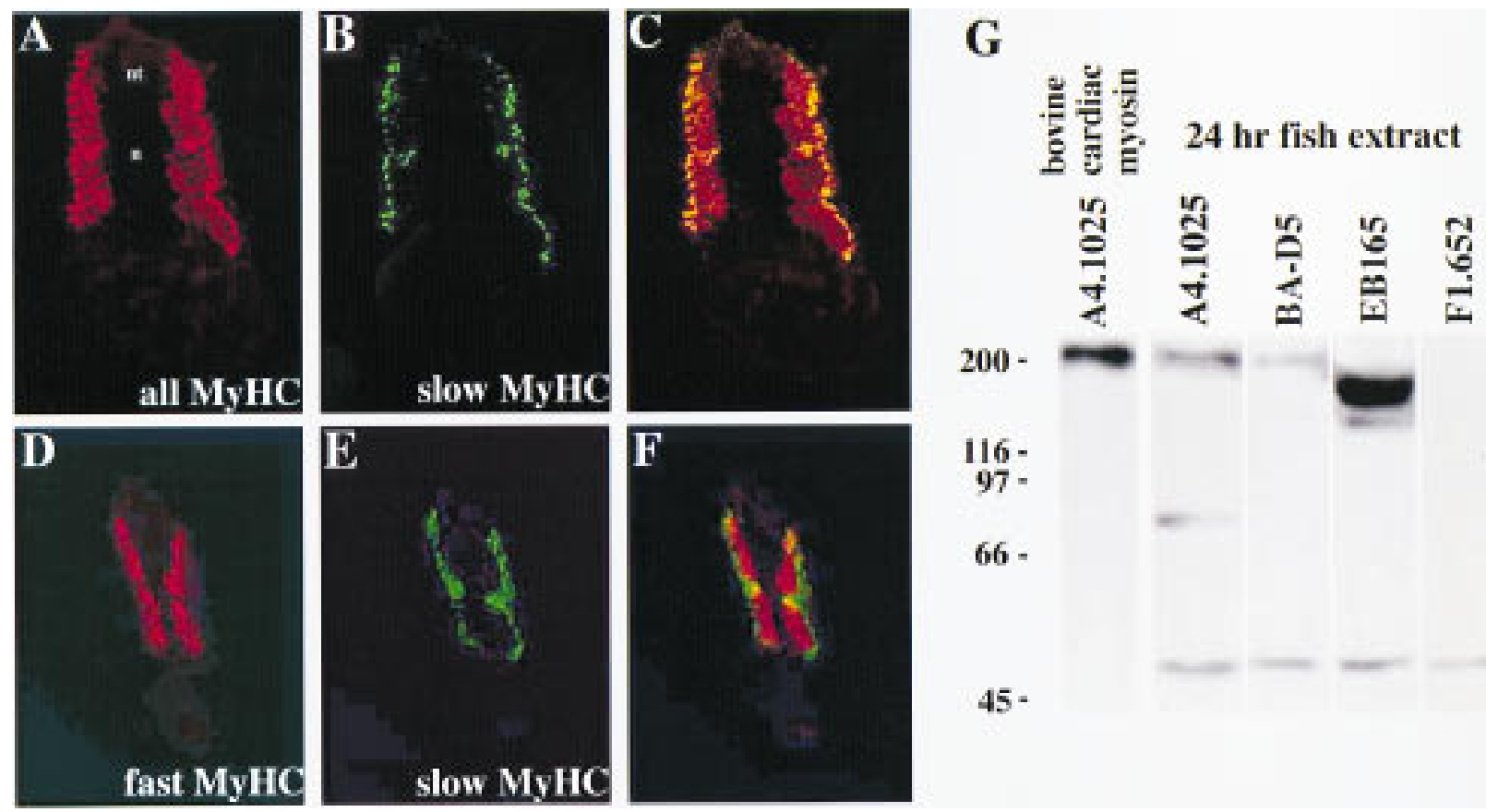

66 -

45.

Figure 1. Slow and fast $\mathrm{MyHC}$ isoform-specific antibodies recognize discrete muscle fiber populations in devel oping embryonic 24-hr zebrafish. Slow BA-D5-reactive MyHC (green; B,C) is present in the outermost layer of A4.1025-reactive cells containing skeletal muscle $\mathrm{MyHC}$ (red; $A, C$ ) in a transverse cryosection through the trunk (A-C). A tail section (D-F) shows that fast EB165-reactive MyHC (red; D,F) was detected in medial fibers that do not express slow MyHC (green; E,F) so that muscle fibers at this stage can be divided into two subpopulations of slow lateral and fast medial cells (C,F). Western analysis (G) using protein extracted from 24-hr zebrafish embryos shows that A4.1025 and BA-D5 recognize major bands that migrate at the same rate as purified bovine cardiac muscle M yHC ( 220 kD). EB165 detects two bands $170 \mathrm{kD}$ that could either reflect degradation of the fast MyHC or an unusual sized $\mathrm{MyHC}$ in zebrafish fast muscle. The lower $\sim 50-\mathrm{kD}$ band is nonspecific because it is also detected with antibody F1.652 to mouse embryonic MyHC that does not react with fish sections. The 75-kD band in the A4.1025 lane reflects some degradation. (n) N otochord; (nt) neural tube.

region of 24-hr zebrafish somites at all anteroposterior positions within the body axis (Fig. 1B,C,E,F). In contrast, EB165, an antibody that detects fast fibers in embryonic and adult chicken muscle (Gardahaut et al. 1992), detects an adjacent nonoverlapping population of medial somitic muscle fibers in the 1-day zebrafish embryo (Fig. 1D,F). A third monoclonal antibody, A4.1025, which reacts with a conserved epitope near the ATPbinding site of all striated muscle $\mathrm{M}$ yHC isoforms examined in a wide variety of species (Dan-Goor et al. 1990), detects both the BA-D5 ${ }^{+}$and $\mathrm{EB} 165^{+}$populations of cells (Fig. 1A,C). All three antibodies reacted with muscle fibers in a striated pattern typical of sarcomeric myosin and Western analysis of 24-hr zebrafish extracts separated by SDS-PAGE demonstrated that all three antibodies detect protein bands at or just under $M_{r} 200,000$, the size of MyHC isoforms (Fig. 1G). Therefore, these anti$\mathrm{MyHC}$ antibodies distinguish slow and fast differentiated muscle cells in the zebrafish embryo.

Slow muscle differentiates before fast muscle in zebrafish embryos

We determined the timing and location of slow and fast muscle differentiation throughout zebrafish somite de- velopment. N ew somites separate from the presomitic paraxial mesoderm in an anterior to posterior order about every half hour between 10.5 and 26 hrs of development at $28^{\circ} \mathrm{C}$ (Westerfield 1995). We observed that $\mathrm{MyHC}^{+}$adaxial cells appeared on each side of the notochord in an anterior-to-posterior order in each somite as it formed (Fig. 2A). Most, if not all, adaxial $\mathrm{MyHC}^{+}$cells also express slow MyHC (Fig. 2B). Fast MyHC was undetectable in 15 somite embryos (Fig. 2C). Therefore, the first population of muscle cells to differentiate in the zebrafish somite are the adaxial cells, and these cells express slow, but not fast, characteristics from their inception.

A recent study by Devoto et al. (1996) has elegantly shown that the differentiated adaxial cells of somites 16-20 in the gut extension region of zebrafish embryos migrate laterally through the somite 3-4 hr postsomitogenesis. Consistent with the results of Devoto et al. (1996), we find that before the 20-somite stage, adaxial slow $\mathrm{MyHC}^{+}$cells in all somites remain medial, but that the adaxial slow $\mathrm{MyHC}^{+}$cells of older somites appear to spread dorsally around the sides of the neural tube and ventrally past the hypochord to form a single layer of medial cells. At about the 20-somite stage the adaxial slow $\mathrm{MyHC}^{+}$cells of the most anterior somites appear to 


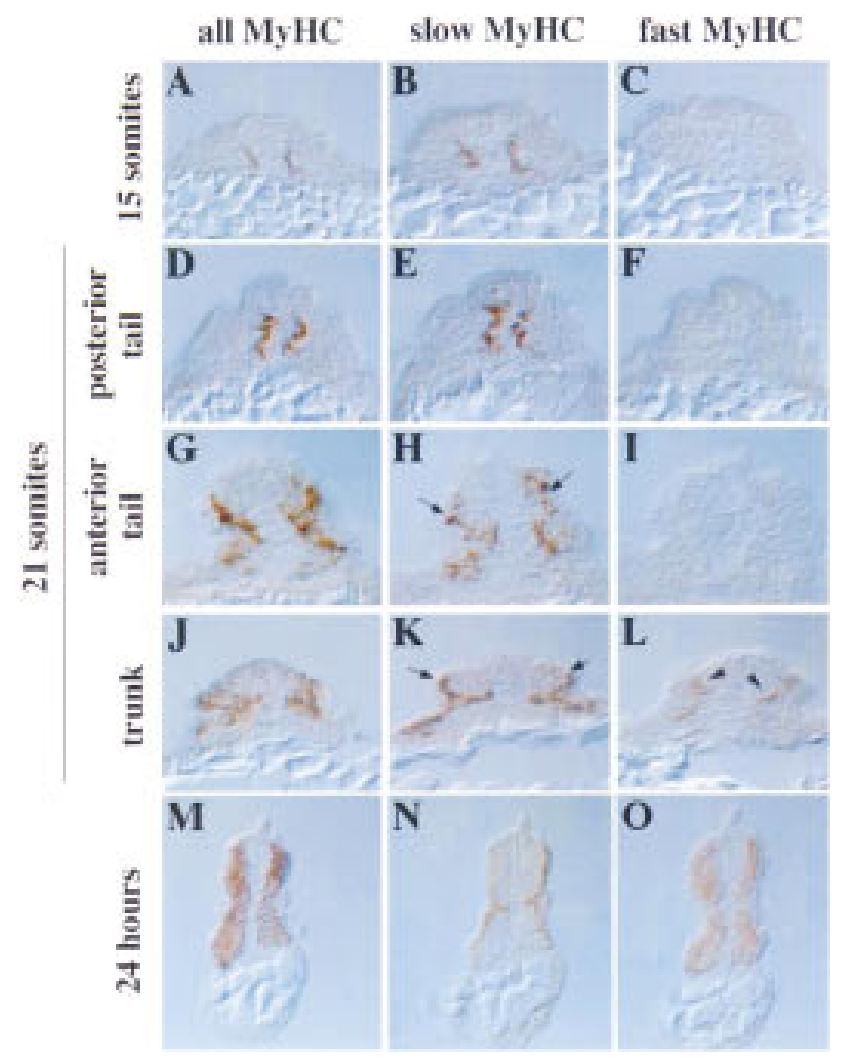

Figure 2. Slow muscle differentiates before fast in zebrafish embryos. (A-C) Serial transverse cryosections of a methanolfixed 15-somite embryo show that muscle first differentiates next to the notochord (A), and expresses slow MyHC (B). Fast $\mathrm{MyHC}(C)$ is undetectable at any level of the embryo. (D-L) At the 21-somite stage, a developmental progression exists along the anteroposterior axis. Posteriorly, slow muscle cells are still medial $(D, E)$ and fast $\mathrm{M} \mathrm{yHC}$ is undetectable $(F)$. However, more anterior sections of the same embryo show loss of slow $\mathrm{MyHC}^{+}$ cells medially and their appearance laterally ( $\mathrm{H}, \mathrm{K}$; arrows). Somite cells medial to slow $\mathrm{MyHC}^{+}$cells initiate differentiation $(G, J)$ and fast $M y H C$ expression ( $L$; arrowheads). Therefore, medial fast muscle differentiates slightly before lateral in each individual somite. (M-O) By $24 \mathrm{hr}$, the slow muscle cells are aligned in a layer one cell thick at the lateral margin $(\mathrm{N})$, and the remaining medial muscle expresses fast $\mathrm{MyHC}(\mathrm{O})$.

migrate laterally, through the undifferentiated somitic mesoderm. Although it is possible that this apparent migration represents a wave of fiber type conversion, we think this unlikely from the earlier findings of Devoto et al. (1996) that early adaxial cells migrate and form slow muscle. The wave of migration sweeps rapidly al ong the embryo from anterior to posterior so that by the 21-somite stage, slow muscle cells of the anterior somites are located at the lateral edge of the somite under the epidermis (Fig. 2J,K), whereas sl ow muscle cells of mid-body somites are found in the center of the somite (Fig. $2 \mathrm{G}, \mathrm{H}$ ) and the most posterior slow muscle cells, are still in the adaxial position (Fig. 2D,E). During the lateral migration of slow muscle cells the differentiation of fast muscle cells commences (Fig. 2F,I,L). No differentiated fast muscle was observed lateral to migrating slow muscle cells. However, strikingly, fast muscle cells are detected medial to the slow muscle cells immediately after the migratory period in each somite (Fig. 2, cf. I and L). By the 26-somite stage, all slow muscle cells in somites 1-21 have migrated laterally (Fig. $2 \mathrm{M}, \mathrm{N}$; data not shown). At this stage fast muscle fills the medial bulk of the somite (Fig. 20). Therefore, the differentiation of a distinct class of fast muscle cells rapidly succeeds the migration of the slow muscle cells past undifferentiated somitic cells.

Notochord defects correlate with lack of slow muscle differentiation

The formation of slow muscle next to notochord suggests that a notochord-derived signal induces slow muscle cells. To test this hypothesis we examined two mutant zebrafish strains that are defective in distinct stages of notochord development. Severely affected bozozok $\left(\mathrm{boz}^{\mathrm{i}}{ }^{2}\right)$ fish do not have visible notochord, lack the notochord and floor plate marker Shh, and completely lack differentiated slow muscle (Fig. 3A-C). At $24 \mathrm{hr}$ of development, when in wild-type embryos adaxial cells have differentiated, migrated, and express slow $\mathrm{MyHC}$ in all somites, no slow MyHC is detected in trunk or tail regions of boz embryos that lack notochord (six of six embryos sectioned; Fig. 3B), al though unaffected sibling embryos appear wild type (data not shown). Mutation of the boz gene does not prevent muscle differentiation per se, because a singl e fused somite of differentiated muscle is present beneath the neural tube, and this expresses fast $\mathrm{M}$ yHC (Fig. 3A,C). N ormal boz function is required for formation of slow muscle, rather than maintenance, as both severely and more mildly affected embryos from a boz heterozygote cross fai led to express detectabl esl ow $\mathrm{MyHC}$ at the 15-somite stage, whereas morphologically normal siblings showed normal slow MyHC expression (data not shown). Therefore, the absence of notochord in the boz mutant is accompanied by the specific loss of slow muscle.

Although boz function is required for notochord formation, it is possible that the wild-type gene might al so be required in paraxial mesoderm to permit differentiation of slow muscle cells. We therefore examined ntl mutant embryos in which midline mesodermal cells are present but fail to differentiate into mature notochord cells. Previous studies have shown that $n t l$ embryos al so lack muscle pioneer cells, a subpopulation of the adaxial cells (Hal pern et al . 1993). ntl is the zebrafish homol og of the Brachyury transcription factor and is expressed in notochord but not in adaxial cells at the time of their differentiation and therefore muscle defects are unlikely to be attributable to a cell-autonomous action of ntl in paraxial mesoderm (Schulte-Merker et al. 1994). In ntl ${ }^{\text {b160 }}$ embryos, notochord precursors are present in anterior regions but absent posteriorly in the region beyond the yolk tube, which is severely truncated (Hal pern et al. 1993; Odenthal et al. 1996; Fig. 3P). We examined ntl ${ }^{\text {b160 }}$ fish for sl ow MyHC expression anticipating that the loss 


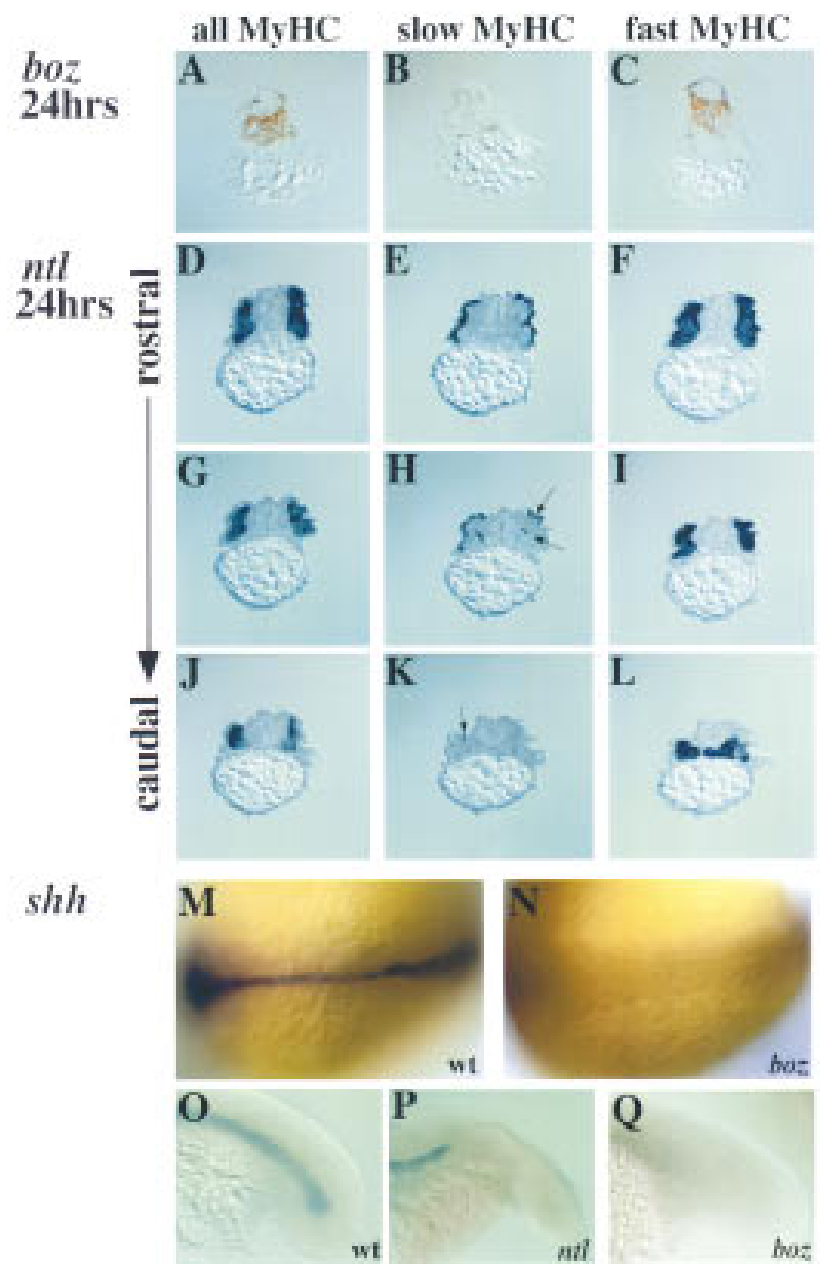

Figure 3. Severe midline defects correlate with loss of slow muscle formation. (A-C) Serial transverse sections of severely affected 24-hr boz embryos, which have no axial mesoderm from gastrulation, have no detectable slow $\mathrm{MyHC}$ (B). A single fused somite (A) expressing fast $\mathrm{MyHC}$ (C) extends under the neural tube (cf. Fig. 2, M-O). (D-L) Successive transverse sections of a 24-hr ntl ${ }^{\text {b160 }}$ embryo. Anterior tail shows normal distribution of muscle fiber types (D-F), except for the lack of muscle pioneers at the dorsoventral midline (E). More posteriorly (G-I), sl ow cells are missing or migrate abnormally (arrows in $\mathrm{H}, \mathrm{K})$. Fast $\mathrm{MyHC}$ appeared unaffected $(\mathrm{F}, \mathrm{I}, \mathrm{L})$. (M-Q) Wholemount in situ mRNA hybridization for shh at 15 somites (M$\mathrm{O}, \mathrm{Q})$ or $24 \mathrm{hr}(\mathrm{P})$. N otochord and floorplate shh expression is completely absent in severe boz embryos ( $N, Q)$, compared with wild type $(\mathrm{M}, \mathrm{O})$. In contrast, only the most posterior shh expression is lacking in $n t l$ mutants $(P) .(M, N)$ Dorsal views of the tail; $(\mathrm{O}-\mathrm{Q})$ lateral views of the tail.

of notochordal maturation might prevent slow muscle formation. Despitetheabsence of muscle pi oneer cells at the dorsoventral midline, slow and fast muscle in anterior regions of ntl embryos appeared normal (Fig. 3D-F). Therefore, mature notochord is not required for slow muscle differentiation. However, more posterior regions of ntl embryos, in which axial mesoderm defects are more severe (Hal pern et al. 1993), showed reduced slow muscle formation and aberrant positioning (Fig. 3G-I). In rare embryos (1/16 serially sectioned) a complete absence of sl ow muscle was observed in the most posterior somite at $24 \mathrm{hr}$ of development, even though extensive differentiated fast muscle was present (Fig. 3J-L). The remaining ntl embryos (15/16) showed regional slow deficits. Therefore, ntl mutant fish demonstrate that although mature notochord is not necessary for slow muscle formation, severe defects in notochord establishment in the tail correlate with loss of slow muscle differentiation.

\section{Shh induces ectopic slow muscle differentiation}

Examination of the muscle phenotype of boz and ntl mutant embryos suggested that notochord-derived signals may determine the slow muscle fate, reminiscent of the induction of floorplate and motoneurons by notochord-derived Shh protein (Ericson et al. 1996) and of muscle pioneer cells by notochord-derived hedgehogs (Currie and Ingham 1996). Consistent with this, shh mRNA is absent from those regions of both boz and ntl embryos that show defects in slow muscle formation (Fig. 3M-Q). To test the possibility that Shh might be a notochord-derived inducer of the slow muscle fate, we injected shh mRN A into two- or four-cell zebrafish embryos to create animals chimeric for shh overexpressing cells. Such injections lead to an easily detectabl e reduced retina phenotype (Krauss et al. 1993). In animals affected for retinal development, we observed an induction of slow MyHC expression across the entire width of the somite in each of 12 serially-sectioned 24-hr embryos (Fig. 4A-C). Strikingly, this expansion occurs at the expense of differentiated fast muscle (Fig. 4C). In those animals in which mosaic segregation of shh mRN A causes partial slow muscle induction, residual fast muscle is observed in regions not expressing sl ow $\mathrm{M} \mathrm{yHC}$ (data not shown). When the same experiment was repeated using an equivalent amount of echidna hedgehog (ehh) mRN A, no defect was detected in any part of 10 embryos serially sectioned (data not shown). Therefore, Shh is a notochord-derived signal capable of inducing slow muscle at the expense of fast.

The wholesale conversion of large areas of somite to slow muscle by Shh has two possible explanations. Shh could induce somitic cells to differentiate as slow muscle prematurely. Alternatively, Shh might not affect the decision of when to differentiate, but simply determine what type of muscle is formed. To address this issue, we examined the effect of ectopic Shh on earlier stage zebrafish embryos. In 15-somitezebrafish embryos, Shh induces a wide region of ectopic lateral differentiated muscle within the somite (46/53 unselected injected embryos, Fig. 4G,H). Ectopic slow muscle differentiation occurred without premature induction of fast muscle tissue (Fig. 4D-F). The premature differentiation of lateral muscle tissue suggested that Shh might induce presomitic mesoderm to differentiate early. However, premature slow muscle differentiation before the normal time of adaxial cell differentiation was not observed in 


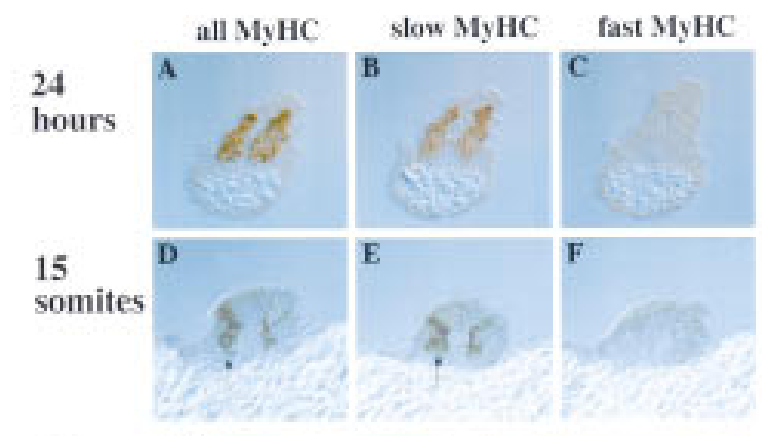

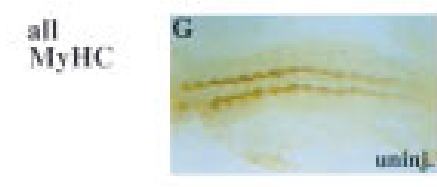

slow MyHC

boz 24 hrs
shh-injected
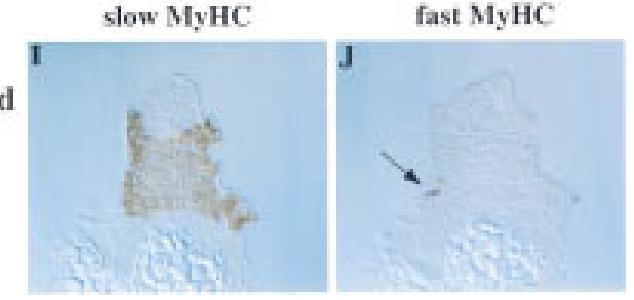

Figure 4. Ectopic overexpression of shh induces extra slow muscle cells in the myotome of wild-type and mutant embryos. (A-C) shh mRN A was microinjected into the zebrafish blastulae at the 2- or 4-cell stage and 24-hr embryos examined in transverse serial cryosections. All differentiated cells in both myotomes contained slow $\mathrm{MyHC}(\mathrm{A}, \mathrm{B})$ and did not express fast $\mathrm{MyHC}(C)$. Some injected embryos showed ectopic slow MyHC and fast $\mathrm{MyHC}$ suppression on only one side, probably caused by mosaic expression of injected mRN A (data not shown). (D-H) Embryos injected with shh mRNA were analyzed at the 15somite stage by whole-mount or cryosection immunohistochemistry. Compared with wild type (G and Fig. $2 A$ ), injected embryos showed bilateral $(H)$ or unilateral $(D$, arrow) expansion of muscle differentiation. Ectopic muscle contained slow ( $E$, arrow), but not fast, $\mathrm{MyHC}(\mathrm{F})$. N ote that al though ectopic lateral muscle is present in the anterior portion of shh-injected embryos $(\mathrm{H}$, left), premature differentiation is not observed in presomitic mesoderm $(\mathrm{H}$, right). $(\mathrm{I}, \mathrm{J})$ Embryos from boz mutant crosses were injected with shh mRN A and severely affected boz embryos (lacking eyes and notochord), were examined by serial cryosection immunohistochemistry. Widespread slow MyHC rescue (I) and supression of fast $\mathrm{MyHC}(\mathrm{l})$ was observed.

either presomitic mesoderm of any of 36 embryos examined at the 15-somite stage (Fig. $4 \mathrm{H}$ ) or in any region of 22 embryos at tail bud stage (data not shown). Therefore, the earliest time somitic cells are competent to become slow muscle in response to Shh is when adaxial cells normally differentiate. However, at this stage, cells in all regions of the somite become competent.

The ability of Shh to induce sl ow muscle is consistent with the lack of slow muscle in regions of zebrafish mutants that lack midline shh expression. This correlation suggests strongly that the reason for the lack of slow muscle in the boz ${ }^{\mathrm{i} 2}$ and the tail of $\mathrm{ntl}^{\mathrm{b} 160}$ mutants is lack of notochord-derived Shh (Concordet et al. 1996). However, the boz gene has not been cloned, so its expression is unknown, and the ntl gene is expressed transiently in presomitic mesoderm, as well as in notochord (Odenthal et al. 1996). This raises the possibility that the lack of slow muscle in these mutants reflects a need for a cell autonomous action of the respective genes in paraxial mesoderm. To address this issue, we overexpressed shh in embryos from boz ${ }^{\mathrm{i} 2}$ mutant crosses and examined the resultant animals for sl ow MyHC expression. Five out of six severely affected boz mutants injected with shh mRNA showed induction of slow MyHC, and suppression of fast MyHC (Fig. 4l, J). Therefore, the boz ${ }^{i 2}$ mutation does not affect the ability of somitic tissue to re spond to Shh and form slow muscle. Moreover, even in the complete absence of notochord Shh is sufficient for the formation of slow muscle.

\section{A limited source of Shh is sufficient to rescue slow muscle}

One limitation of overexpression of Shh by mRNA injection is that ectopic Shh is expressed in regions of the animal never normally exposed to Shh and at above normal physiological levels. This might perturb signals necessary for muscle development from other embryonic tissues. To examine slow muscle differentiation in response to localized lower levels of shh expression we took advantage of the floating head (flh) mutation. Animals homozygous for flh are defective in notochord maturation because of mutation in a homeobox-containing gene expressed chiefly in the notochord $(\mathrm{H}$ alpern et al. 1995; Tal bot et al. 1995) and, like ntl embryos, lack notochords and muscle pioneers. However, unlike ntl, $\mathrm{fl}$ h exhibits transdifferentiation of notochord tissue into muscle (Halpern et al. 1995). We examined flh embryos for muscle differentiation and found that it occurs in an altered location. Cells in the embryonic midline, not those in the adaxial position, are the first to differentiate in flh embryos (Fig. 5A,B). This differentiation is immediately beneath the presumptive floorplate that expresses Shh sporadically (Fig. 5C). Despite the unusual location of these muscle cells, they express slow, but not fast, MyHC (Fig. 5D-F), spread dorsally around the neural tube and ventrally in the midline, and appear able to undergo lateral migration to take up a normal position beneath the ectoderm by $24 \mathrm{hr}$ of development (Fig. 5GI). Therefore, in flh embryos, apparently normal slow muscle cells differentiate beneath the residual floorplate-the sole remaining location where somitic mesoderm abuts shh-expressing tissue.

The discontinuous location of shh-expressing cells in the floorplate of flh mutants (Fig. 5C) allows an examination of the relationship between the location of Shh and sl ow muscle differentiation. At the posterior limit of MyHC-containing cells in flh we found no correlation between the location of remaining floorplate shh expression and medial slow myoblast differentiation. Muscle differentiates both immediately beneath and between islands of shh-expression (Fig. 5C). This data suggested 


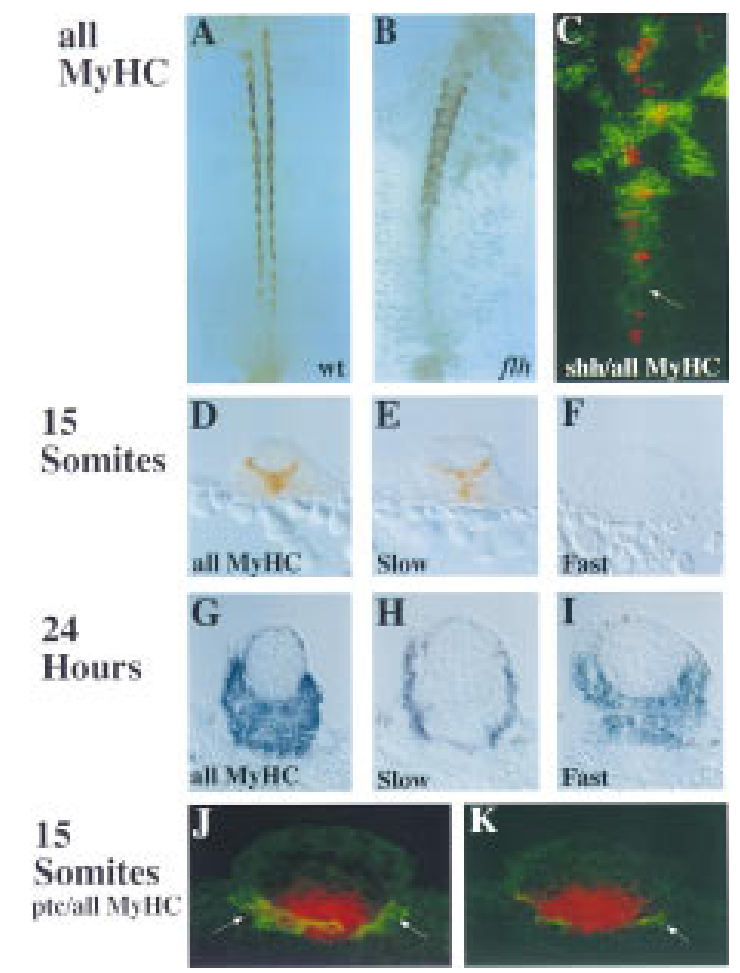

Figure 5. Slow muscle forms beneath the floorplate in flh embryos. (A-C) Differentiated muscle visualized by MyHC-staining in whole-mount 15-somite wild-type $(A)$ or flh $(B, C)$ embryos observed after flat-mounting. Dual labeling for shh mRN A (red; C) and MyHC (green; C) confirmed that the most posterior differentiated muscle was at the midline (arrow, C). (D-I) Transverse cryosections show that differentiated muscle in flh midline mesoderm expresses slow but not fast $\mathrm{MyHC}$ at 15 somites (D-F). By $24 \mathrm{hr}$, flh embryos have a single fused myotome $(G)$, with lateral slow and medial fast muscle $(H, I)$. Despite the ectopic location of formation of slow muscle cells in the midl ine the slow muscle cells appear to migrate normally so that the only detectable residual sl ow muscle defect is lack of muscle pioneers. $(\mathrm{J}, \mathrm{K})$ Dual labeling for $\mathrm{MyHC}$ (green) and ptc1 mRNA (red) in the two most posterior M yHC-containing serial sections of a 15-somite flh embryo. Newly differentiating muscle cells close to the midline do not al ways express detectable ptcl (arrows), even though ptcl is expressed abundantly in the mesoderm underlying residual floor plate $(K)$.

that terminal differentiation of slow muscle is not induced directly by Shh. Further evidence that muscle differentiation, per se, is not induced by Shh came from examining the up-regulation of patched1 (ptc1) mRNA in flh mutant embryos. ptc1, a zebrafish homol og of Drosophila patched, is a Shh receptor (Stone et al. 1996), and is up-regulated adjacent to residual shh expression in flh embryos both at somitic and presomitic anteroposterior positions (Concordet et al. 1996). Therefore, mesodermal cells are first exposed to Shh long before muscle differentiation commences. M oreover, even the most recently differentiated muscle cells in flh embryos frequently do not express high levels of ptcl mRNA, despite adjacent mesoderm expressing ptcl abundantly (Fig. 5J,K). There- fore, although Shh induces ptc1 locally al ong the entire length of the flh embryo, there is a delay after Shh exposure before the appearance of differentiated sl ow muscle cells. In addition, by the time sl ow muscle differentiates, any spatial correlation between shh expression and myogenic cells has been lost. Taken together, these data suggest that Shh may initiate slow myoblast formation, but that continued exposure is not required to trigger the terminal differentiation of slow muscle fibers.

\section{Discussion}

Shh and slow muscle induction

Several lines of evidence show that adaxial slow muscle formation in zebrafish embryos is controlled by Shh. First, slow muscle differentiation occurs next to the notochord, which expresses shh. This observation confirms and extends the results of Devoto et al. (1996), who observed that adaxial cells giveriseto sl ow muscle markers after they mi grate lateral ly through the somite. Our data show that adaxial cells are al ready determined to form slow muscle as soon as they differentiate into skeletal muscle myosin-expressing myocytes. Second, a lack of slow muscle correlates with a lack of shh expression in mutant fish. Third, ectopic expression of shh can induce conversion of most, if not all, somitic cells to slow muscle, at the expense of fast muscle. Fourth, even in the absence of notochord, injection of shh mRNA can rescue formation of sl ow muscle. Fifth, in the absence of the normal Shh si gnal from notochord, a localized source of Shh correlates with induction of ectopic slow muscle cells, which then migrate in a similar fashion to slow muscle cells in wild-type embryos. These data are supported by the wild-type expression of a Shh receptor, ptcl, that is up-regulated in adaxial cells within presomitic mesoderm indicating that these cells are re sponding to hedgehog (hh) signaling (Concordet et al. 1996). Taken together, these findings make a strong case for notochord-derived Shh being the normal inducer of the differentiated slow adaxial muscle cell fate in the zebrafish.

\section{Shh induces adaxial slow myoblasts}

How might Shh induce the slow muscle fate in zebrafish? Muscle is formed in two steps-mesodermal commitment to the proliferative myoblast, followed by terminal differentiation into the postmitotic muscle fiber. Several lines of evidence suggest that Shh is responsible for induction of slow muscle precursor cells, rather than the terminal differentiation of slow muscle, per se. First, the muscle-specific transcription factor myoD is initially detectable in adaxial precursors located adjacent to shh-expressing cells within the embryonic shiel d several hours before their terminal differentiation at around the time of somitogenesis (Weinberg et al. 1996). This expression of myoD before terminal differentiation is also detected in adaxial cells at later stages when posterior somites arise from the tail bud. Second, zebrafish mutants like boz and ntl that lack sl ow muscle, al so lack 
the early adaxial myoD expression, and this correlates with a lack of axial Shh (Fig. 3; Concordet et al. 1996; Odenthal et al. 1996; Weinberg et al . 1996; Schier et al. 1997). Third, Shh signaling can induce premature myoD in lateral presomitic cells (Concordet et al. 1996; Hammerschmidt et al. 1996; Weinberg et al. 1996). We show that these ectopic myoD-expressing cells in lateral somites have other features, such as the direction and timing of their differentiation and sensitivity to additional hh signals (Currie and Ingham 1996), suggesting that the terminal differentiation of these cells into sl ow muscle is prefigured at the myoblast level. Fourth, our examination of the flh mutant suggests that adaxial myoblasts differentiate into slow muscle fibers independent of their proximity to residual shh-expressing floor plate cells, and independent of their exposure to Shh during the period of terminal differentiation, as assayed by ptc1 expression (Concordet et al . 1996; M arigo and T abin 1996). Therefore, at early stages M yoD may mark cells that, although not yet differentiated, have become committed to a slow myoblast lineage.

Previ ous data have suggested that the combined action of notochord-derived Shh and Ehh induces zebrafish muscle pioneer subset of the adaxial slow muscle cells (Currie and Ingham 1996). The data in the present paper demonstrate that Ehh is not required for production of the nonpioneer adaxial slow muscle cells. Ehh is not expressed in notochord of $\mathrm{ntl}{ }^{\mathrm{b} 160}$ (Currie and Ingham 1996), yet nonpioneer slow muscle cells form and migrate normally in the anterior of $\mathrm{nt}^{\mathrm{b} 160}$ embryos where Shh alone is expressed (Fig. 3). Similarly, in flh mutants, which lack notochord and ehh expression (Currie and Ingham 1996), apparently normal nonpioneer adaxial cells are formed ectopically close to residual floorplate
Shh. M oreover, Ehh does not appear ableto substitute for Shh in the induction of nonpioneer adaxial cells as injection of ehh mRNA into wild-type embryos did not induce ectopic slow MyHC. These data support the hypothesis that in vivo Shh and Ehh serve distinct roles.

The finding that Shh induces slow myoblasts suggests a new view of the steps of muscle differentiation that contrasts with the traditional model in which somitic cells first become myoblasts and only subsequently specialize into one particular myoblast subclass. We suggest, as summarized in Figure 6, that the decision whether to form one type of muscle or another is made concurrently with myoblast commitment to the muscle lineage. This scheme concurs with conclusions from anal ysis of the you-type zebrafish mutants (van Eeden et al. 1996). Such a view al so fits well with studies in Drosophila demonstrating that distinct extracellular signals serve to commit each founder myoblast to a particular muscle type (Baylies et al. 1995). However, it is possible that presomitic cells could be committed to myogenesis before myoD expression. Although $M y o D$ is the first MRF to be expressed in birds, Myf- 5 is the earliest MRF to appear at high levels in mammalian somites (Ott et al. 1991), and Pax-3 can induce myogenesis (Maroto et al. 1997; Tajbakhsh et al. 1997). Furthermore, whether all myoblasts are committed to form particular types of muscle from their inception is unclear. Whatever the case, our data show that Shh induces adaxial myoblasts that adopt a slow muscle fate.

\section{Zebrafish fast muscle formation}

Shh is not necessary for fast muscle formation. boz fish that lack Shh produce abundant fast muscle throughout
Figure 6. Three phases of zebrafish muscle development. A model in which presomitic mesoderm gains competence to respond to Shh early in development in wild-type zebrafish. The result of exposure to notochord-derived Shh at this stage is a slow myoblast phenotype involving myoD expression and up-regulation of ptcl (orange). However, a second event, either intrinsically timed within the slow myoblast, or in the form of a signal from outside of the somite (indicated by ? on the diagram, but unlikely to be either Shh or notochord-derived), is required for the slow myoblast to differentiate into a fiber (red). Simultaneously, the MyoD-positive myoblast state in lateral somitic cells arises independent of notochord-derived signals (yellow). Later, adaxial slow fiber migration and concurrent differentiation of lateral myoblasts into fast muscle (green) is timed by a third event(s). Fast fiber differentiation is independent of slow fiber migration, although the converse may not be true.

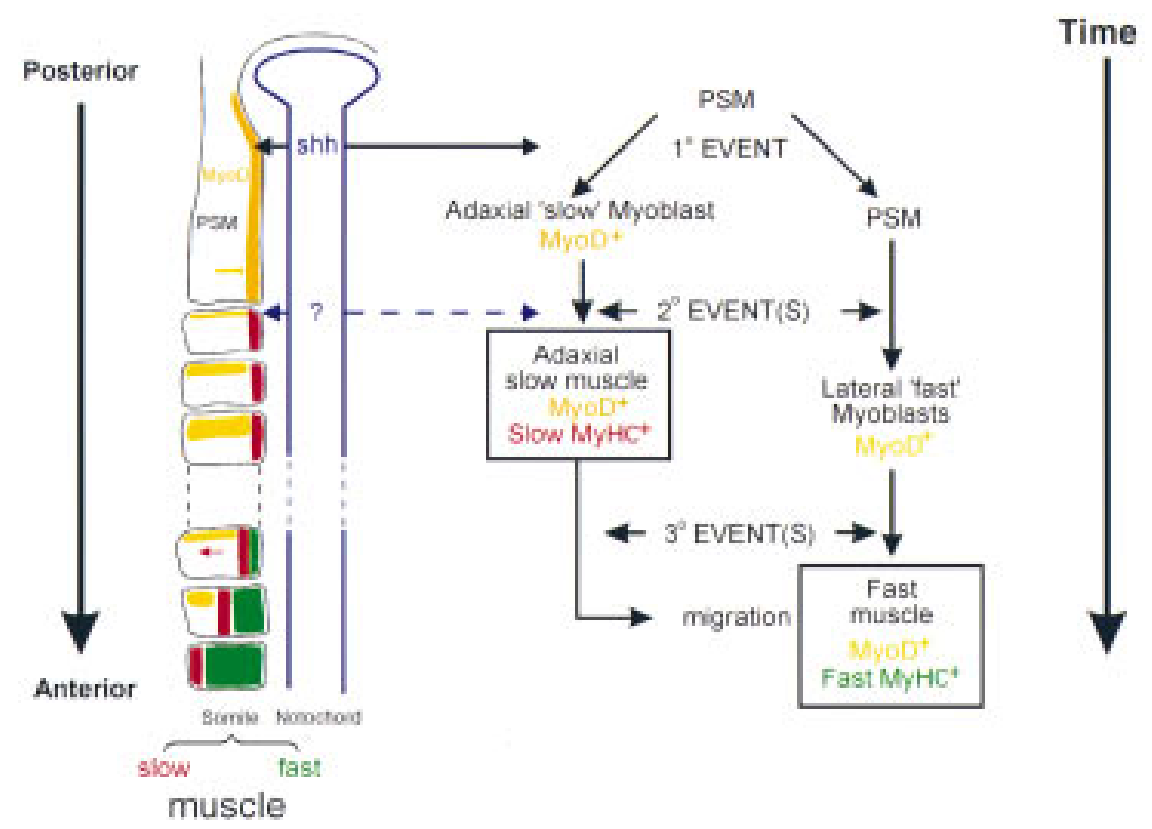


the somite. Moreover, the normal myoD-expressing myoblasts stripes across the posterior border of the somite form at the normal time just before somitogenesis in embryos that lack shh expression (Odenthal et al. 1996). Therefore, in zebrafish, M yoD may mark commitment to a myoblast fate irrespective of the type of myoblast formed. We find that cells that are initially lateral within the somite differentiate into fast muscle. They may be committed to formation of fast muscle from the inception of myoD expression.

\section{Timing of myoblast differentiation}

We show that ectopic Shh can induce premature muscle differentiation in the lateral somite. However, premature differentiation was slow, rather than fast, and was only observed at the normal time of slow adaxial cell differentiation. Therefore, no somite cel Is are competent to differentiate in response to Shh until around the time of somitogenesis, even though myoD is expressed earlier. This may explain why slow muscle does not appear earlier in development even though shh is expressed in the developing notochord from gastrulation onwards (Krauss et al. 1993), and is presumably secreted because ptcl, a marker of Shh exposure, is expressed highly in adjacent presomitic cells (Concordet et al. 1996). Two alternative models could explain the delay between MyoD and slow myosin expression (Fig. 6). In one model, the delay is caused by an intrinsically timed maturation of the somitic cells. Although cell division is not extensive in zebrafish somites (Kimmel and Warga 1987), Shh might induce myoblasts committed to division followed by differentiation as it can be a somitic mitogen (Fan et al. 1995). Mammalian myoblasts show such behavior in vitro (Quinn et al. 1985), which is reminiscent of the induction of division followed by terminal differentiation in Drosophila lamina gangl ia neurons in response to retinal neuron-derived hh (Huang and Kunes 1996). Alternatively, in the second model, extracellular signals may control terminal differentiation. In amniotes, other signals can cooperate with Shh to regulate myogenesis (M unsterberg et al. 1995; Stern et al . 1995; Pourquie et al . 1996), and a variety of growth factors repress myoblast differentiation in culture. Ventral axial structures are unlikely sources of such signals as Shh is sufficient to induce slow $\mathrm{MyHC}$ in boz embryos that fail to form notochord or floor pl ate. Regardless of the mechanism by which the timing of terminal adaxial slow muscle differentiation is controlled, our data show that similar mechanisms can operate in the lateral somite to control ectopic slow muscle differentiation in response to Shh.

\section{Evolutionary conservation of muscle patterning}

We found that in fish embryos the first skel etal muscle fibers to form are slow from the time of their inception. Later, a second wave of fibers, which ultimately constitute the majority of all fibers, differentiate as fast muscle. In amni ote limbs muscle fibers also form in two waves, an early primary population that express slow (and embryonic) myosin and later secondary cells that, forming in close association with primary fibers, express fast (and embryonic) myosin from their inception (Kelly and Rubinstein 1980; Vivarelli et al. 1988; Cho et al. 1994). We suspect that zebrafish embryos may also express an embryonic myosin in both slow and fast fibers as the immunoreaction with our all-myosin antibody was stronger than with the specific slow and fast antibodies. M oreover, both adaxial and nonadaxial cells react from their inception with an antibody that detects embryonic myosin (Devoto et al. 1996). These analogies suggest that adaxial and nonadaxial somitic muscle cells in the zebrafish may be evolutionary homologs of amniote primary and secondary muscle fiber generations. Amniote secondary fibers form overlying the neuromuscular junctions of primary fibers and it has been suggested that signals from the forming neuromuscular junction region may be required to initiate secondary fiber formation (Duxson et al. 1989). This is not the case in the zebrafish as absence of differentiated sl ow primary fibers does not prevent differentiation of fast muscle despite the striking correlation between the lateral migration of slow fibers and the differentiation of fast fibers. The converse relationship, that fast fiber differentiation might cause slow fiber migration, remains a possibility. $\mathrm{N}$ evertheless, the close similarities between fish and amniote fiber generation suggest that the common ancestor had two steps of muscle patterning: early fibers being slow and later fast.

There are further analogies between amniote and fish myogenesis. Amniote primary fibers are of several distinct fiber types that prefigure later muscle characteristics (Crow and Stockdale 1986), even though all express some form of slow M yHC (Kelly and Rubinstein 1980; Vivarelli et al. 1988; Page et al. 1992; Hughes et al. 1993). Slow adaxial cells in the zebrafish are also composed of two subpopulations, the muscle pioneer cells which express engrailed, and the nonpioneer adaxials. Engrailed proteins al so mark a subpopulation of muscle cells in the jaw muscle of the zebrafish (Hatta et al. 1990). The data reported in the present paper, together with the previous findings that a second notochord-derived signal (Hal pern et al . 1993), provided by Ehh (Currie and Ingham 1996), is responsible for regulating the formation of muscle pioneer cells, suggest that hh signaling mol ecules may regulate the diversity of muscle fiber types formed in the early fish embryo. Banded hedgehog is al so expressed in particular regions of the Xenopus somite (Ekker et al. 1995). Whether similar signals control muscle patterning in amniotes remains to be determined.

\section{Hedgehogs and vertebrate myogenesis}

Secretion of Shh from notochord has been shown to induce floorplate markers in anterior (although not posterior) zebrafish central nervous system (CNS) and both floorplate and motoneurons in amni ote neural tube (Echelard et al. 1993; Krauss et al. 1993; Roelink et al. 1994; 
Ericson et al . 1996). The role of Shh in somite patterning has been less clear. In amniotes, in which much of the somite becomes sclerotome, either ectopic notochord or shh-expressing cells can induce extra sclerotome at the expense of dermomyotome markers (Fan and TessierLavigne 1994). Conversely, shh ${ }^{-1-}$ mice have deficits in sclerotomal derivatives (Chiang et al. 1996). On the other hand, in both chick and zebrafish, overexpression of shh induces ectopic myoD expression, suggesting a myogenic action (Johnson et al. 1994; Concordet et al. 1996; Weinberg et al . 1996). M oreover, shh ${ }^{-1-}$ mice show defects in medial muscle formation (Chiang et al. 1996) and notochord can induce avian myogenesis (Pownall et al. 1996). So Shh may regulate formation of both ventral and more dorsal somitic tissues. Action of Shh at distinct concentrations or times (Ericson et al. 1996), or in collaboration with other factors (Munsterberg et al. 1995; Stern et al. 1995; Pourquie et al. 1996), could determine the outcome of Shh signaling.

Induction of distinct myoblast types and the subsequent control of their terminal differentiation may account for the numerous signals capable of influencing somite myogenesis. If equivalents of Shh-dependent adaxial cells exist in amniotes, we would expect that particular muscle markers are not distributed uniformly between distinct muscle cell types in the developing dermomyotome. In amniotes, MRFs are the earliest known definitive myogenic markers. Expression of at least one MRF is obligatory for myogenesis in mice (Rudnicki et al. 1993). MRFs are expressed at low levels in presomitic mesoderm, which has the capacity to form muscle in dissociated cell culture (George-Weinstein et al. 1994; Lin-Jones and Hauschka 1996). However, two myoblast populations arise with distinct temporal and spatial patterns within the dermomyotome: The first initially expresses myf- 5 in medial regions and the second myoD in lateral regions (Cossu et al. 1996a; Maroto et al. 1997; Tajbakhsh et al. 1997). That shh ${ }^{-1-}$ mice have reduced expression of medial myf-5 but no detectable change in lateral myoD expression (Chiang et al. 1996) suggests a role for Shh in induction of the medial population. Inhibitory signals, such as BM P4 (Fan and Tessier-Lavigne 1994; Cossu et al . 1996b; Pourquie et al . 1996), may function in vivo to suppress overt myogenic phenotypes in the lateral compartment that generates limb and body wall muscle and may have no homologous process in most zebrafish somites. So generation of further diversity within the dorsomedial myogenic compartment could be a role of Shh in amniote myogenesis. Distinct populations of slow and fast fibers may be present in amniote myotome (Dhoot 1994). In this paper, we have shown that in zebrafish, Shh regulates formation of myotomal sl ow muscle. Much slow muscle in amniotelimbs is located near developing bone that expresses indian hedgehog (Bitgood and M CM ahon 1995; Vortkamp et al. 1996). Moreover, motoneurons, which strongly influence muscle development, can express shh (Bitgood and M cM ahon 1995; Stone et al . 1996), raising the possibility that diverse hh proteins may regulate muscle fiber diversification.

\section{Materials and methods}

\section{Zebrafish lines and maintenance}

Wild-type and heterozygote mutant breeding fish were maintained at $28.5^{\circ} \mathrm{C}$ on a $14-\mathrm{hr} / 10-\mathrm{hr}$ light cycle. We obtained $\mathrm{fl}^{\mathrm{n} 1}$ from the University of N ewcastle-upon-Tyne, $\mathrm{nt}^{\mathrm{b} 160}$ from the University of Oregon, and bozi2 was isolated in the Ingham laboratory (P.D. Currie., T. Schilling, G. Bergemann, and P.W. Ingham, unpubl.). boz ${ }^{i 2}$ fish exhibit a variable phenotype with defects ranging from reduced notochords to a severe lack of axial mesoderm at all rostro-caudal levels. Of 142 progeny of a heterozygous cross examined at $\mathrm{F}_{2}-\mathrm{F}_{4}, 20$ (13\%) showed complete absence of eyes and notochord. A further 25 (17\%) showed a partial phenotype with variable eyes and the anterior half of the notochord missing. These, and a number of other aspects of the phenotype, are strongly reminiscent of boz mutant fish (Solnica-Krezel et al. 1996). Complementation analysis by a cross of heterozygous boz ${ }^{\mathrm{i} 2}$ with boz ${ }^{\mathrm{m} 168}$ has shown reduced eyes and notochord in 3 out of 30 progeny. We therefore tentatively conclude that these genes are allelic. However, because of the incomplete penetrance of boz, definitive demonstration of allelism awaits the mapping of the mutation. Embryos were collected by natural spawning and staged by anatomical markers according to Westerfield (1995). Prim-5 stage embryos are referred to as $24 \mathrm{hr}$.

\section{RNA injection}

RNA injections were performed as described (Currie and Ingham 1996).

\section{Immunohistochemistry}

The slow and fast MyHC antigens are destroyed by aldehyde fixatives, so embryos were fixed by incubating for 5 min each in graded methanols, rehydrated in $0.1 \%$ Tween 20 , serially cryosectioned, and stained. However, preservation of younger embryos was better after staining in whole-mount, followed by post-fixation in $4 \%$ paraformaldehyde for $4 \mathrm{hr}$ at $4^{\circ} \mathrm{C}$ before cryosectioning. Primary monoclonal antibody supernatants of A4.1025 (Dan-Goor et al. 1990) and BA-D5 (Schiaffino et al. 1989) were diluted 1:10. EB165 monoclonal ascites was used at 1:5000 (Gardahaut et al. 1992). First antibodies were detected with biotin-conjugated horse-derived anti-mouse IgG (Vector), Vectastain ABC Elite Peroxidase kit (Vector), and visual ized using $0.5 \mathrm{mg} / \mathrm{ml}$ of diaminobenzidine with (black stains) or without (brown stains) $0.03 \% \mathrm{CoCl}_{2}$ enhancement. Cryosections for dual immunofluorescence had IgG first antibodies detected with Cappell goat anti-mouse IgG ( $\gamma$-specific) Texas red. After a mouse IgG block, biotinylated BA-D5, prepared using Pierce NHS-Biotin reagent, was detected with Dako streptavidinFITC. Sections were mounted in $150 \mathrm{mg} / \mathrm{ml}$ of polyvinyl alcohol, $30 \%$ glycerol PBS with DABCO antifade, and photographed by confocal microscopy.

\section{Western blots}

Embryos were dechorionated, deyolked, and homogenized manually on ice for $10 \mathrm{~min}$ in $63 \mathrm{~mm}$ Tris- $\mathrm{HCl}$ (pH 6.8), 10\% glycerol, 5\% $\beta$-mercaptoethanol, 3.5\% SDS, 0.2 mM PM SF, 0.5 $\mu \mathrm{M}$ aprotinin, and $0.5 \mu \mathrm{M}$ leupeptin. Samples were microcentrifuged for $5 \mathrm{~min}$ at $4^{\circ} \mathrm{C}, 0.01 \%$ bromophenol blue added to the supernatant, the equival ent of 10 embryos run on each lane of a $7.5 \%$ acrylamide denaturing gel at $200 \mathrm{mV}$ for $30 \mathrm{~min}$, and el ectroblotted onto nitrocel lulose (Amersham). Purified bovine cardiac myosin was a kind gift of Dr. John Sleep (The Randall 
Institute, London, UK). Nitrocellulose strips were blocked in $5 \%$ milk powder PBS/Az overnight, washed, and incubated with A4.1025 (1:10), BA-D5 (1:10), F1.652 [1:10; Webster et al. 1988)], or EB165 (1:250) for $2 \mathrm{hr}$ at room temperature. After washing, primary antibody was detected with horseradish peroxidase-conjugated sheep anti-mouse IgG $\mathrm{F}(\mathrm{ab})_{2}$ and an ECL kit (Amersham).

\section{Acknowledgments}

We thank Steve Wilson and Nigel Holder for fish from their BBSRC-funded facility, Everett Bandman for EB165 ascites, John Sleep for bovine cardiac myosin, and Steve Devoto, M onte Westerfield, and Wolfgang Driever for showing us manuscripts before publication. We thank Steve Wilson, Patricia Salinas, and members of our laboratories for hel pful comments on the manuscript, and T. Schilling and G. Bergemann for participation in the mutant screen. This work is supported by the M edical Research Council (S.M.H. and C.S.B.), the Imperial Cancer Research Fund, and a Human Frontier Science Program grant (P.W.I.).

The publication costs of this article were defrayed in part by payment of page charges. This article must therefore be hereby marked "advertisement" in accordance with 18 USC section 1734 solely to indicate this fact.

\section{References}

Baylies, M.K., A. Martinez-Arias, and M. Bate. 1995. wingless is required for the formation of a subset of muscle founder cells during Drosophila embryogenesis. Development 121: 38293837.

Bitgood, M.J. and A.P. McMahon. 1995. Hedgehog and Bmp genes are coexpressed at many diverse sites of cell-cell interaction in the mouse embryo. Dev. Biol. 172: 126-138.

Bober, E., B. Brand-Saberi, C. Ebensperger, J. Wilting, R. Balling, B.M. Paterson, H.-H. Arnold, and B. Christ. 1994. Initial steps of myogenesis in somites are independant of influence from axial structures. Development 120: 3073-3082.

Buffinger, N. and F.E. Stockdale. 1995. M yogenic specification of somites is mediated by diffusible factors. Dev. Biol. 169: $96-108$.

Chiang, C., Y. Litingtung, E. Lee, K.E. Young, J.L. Corden, H. Westphal, and P.A. Beachy. 1996. Cyclopia and defective axial patterning in mice lacking Sonic hedgehog gene function. Nature 383: 407-413.

Cho, M., S.M. Hughes, I. Karsch-Mizrachi, M. Travis, L.A. Leinwand, and H.M. Blau. 1994. Fast myosin heavy chains expressed in secondary mammalian muscle fibres at the time of their inception. J. Cell Sci. 107: 2361-2371.

Concordet, J.-P., K.E. Lewis, J.W. Moore, L.V. Goodrich, R.L. Johnson, M.P. Scott, and P.W. Ingham. 1996. Spatial regulation of a zebrafish patched homologue reflects the roles of sonic hedgehog and protein kinase A in neural tube and somite patterning. Development 122: 2835-2846.

Cossu, G., R. Kelly, S. Tajbakhsh, S. Di Donna, E. Vivarelli, and M. Buckingham. 1996a. Activation of different myogenic pathways: myf- 5 is induced by the neural tube and $M$ yoD by the dorsal ectoderm in mouse paraxial mesoderm. Development 122: 429-437.

Cossu, G., S. Tajbakhsh, and M. Buckingham. 1996b. How is myogenesis initiated in the embryo? Trends Genet. 12: 218222.

Crow, M.T. and F.E. Stockdale. 1986. Myosin expression and special ization among the earliest muscle fibres of the devel- oping avian limb. Dev. Biol. 113: 238-254.

Currie, P.D. and P.W. Ingham. 1996. Induction of a specific muscle cell type by a hedgehog-like protein in zebrafish. Nature 382: 452-455.

Dan-Goor, M., L. Silberstein, M. Kessel, and A. Muhlrad. 1990. Localization of epitopes and functional effects of two novel monoclonal antibodies against skeletal muscle myosin. J. Muscle Res. Cell Motil. 11: 216-226.

Devoto, S.H., E. M elancon, J.S. Eisen, and M. Westerfield. 1996. Identification of separate slow and fast muscle precursor cells in vivo, prior to somite formation. Development 122: 3371-3380.

Dhoot, G.K. 1994. Mammalian myoblasts become fast or slow myocytes within the somitic myotome. J. Muscle Res. Cell Motil. 15: 617-622.

DiM ario, J.X., S.E. Fernyak, and F.E. Stockdale. 1993. M yoblasts transferred to the limbs of embryos are committed to specific fibre fates. Nature 362: 165-167.

Duxson, M.J., Y. Usson, and A.J. Harris. 1989. The origin of secondary myotubes in mammalian skeletal muscles: Ultrastructural studies. Development 107: 743-750.

Echel ard, Y., D.J. Epstein, B. St.-Jacques, L. Shen, J. M ohler, J.A. McMahon, and A.P. McMahon. 1993. Sonic hedgehog, a member of a family of putative signalling molecules implicated in regulation of CN S and limb polarity. Cell 75: 14171430.

Ekker, S.C., L.L. McGrew, C.J. Lai, J.J. Lee, D.P. Von Kessler, R.T. Moon, and P.A. Beachy. 1995. Distinct expression and shared activities of members of the hedgehog gene family of Xenopus laevis. Development 121: 2337-2347.

Ericson, J., S. M orton, A. Kawakami, H. Roelink, and T.M. Jessell. 1996. Two critical periods of Sonic Hedgehog signaling required for the specification of motor neuron identity. Cell 87: 661-673.

Fan, C.-M. and M. Tessier-Lavigne. 1994. Patterning of mammalian somites by surface ectoderm and notochord: Evidence for sclerotome induction by a hedgehog homolog. Cell 79: 1175-1186.

Fan, C.-M ., J.A. Porter, C. Chiang, D.T. Chang, P.A. Beachy, and M. Tessier-Lavigne. 1995. Long-range sclerotome induction by sonic hedgehog: Direct role of the amino-terminal cleavage product and modulation by the CAMP signalling pathway. Cell 81: 457-465.

Felsenfeld, A.L., M. Curry, and C.B. Kimmel. 1991. The fub-1 mutation blocks initial myofibril formation in zebrafish muscle pioneer cells. Dev. Biol. 148: 23-30.

Gamel, A.J., B. Brand-Saberi, and B. Christ. 1995. Halves of epithelial somites and segmental plate show distinct muscle differentiation behavior in vitro compared to entire somites and segmental plate. Dev. Biol. 172: 625-639.

Gardahaut, M .F., J. Fontaine-Perus, T. Rouaud, E. Bandman, and R. Ferrand. 1992. Developmental modulation of myosin expression by thyroid hormone in avian skeletal muscle. Development 115: 1121-1131.

George-Weinstein, M., J.V. Gerhart, G.J. Foti, and J.W. Lash. 1994. M aturation of myogenic and chondrogenic cells in the presomitic mesoderm of the chick embryo. Exp. Cell Res. 211: 263-274.

Goulding, M., A. Lumsden, and A.J. Paquette. 1994. Regulation of Pax-3 expression in the dermamyotome and its role in muscle devel opment. Devel opment 120: 957-971.

Halpern, M.E., R.K. Ho, C. Walker, and C.B. Kimmel. 1993. Induction of muscle pioneers and floor plate is distinguished by the zebrafish no tail mutation. Cell 75: 99-111.

Hal pern, M.E., C. Thisse, R.K. Ho, B. Thisse, B. Riggleman, B. Trevarrow, E.S. Weinberg, J.H. Postlethwait, and C.B. Kim- 
mel. 1995. Cell-autonomous shift from axial to paraxial me sodermal development in zebrafish floating head mutants. Development 121: 4257-4264.

Hammerschmidt, M., M.J. Bitgood, and A.P. McMahon. 1996. Protein kinase $A$ is a common negative regulator of hedgehog signalling in the vertebrate embryo. Genes \& Dev. 10: 647-658.

Hatta, K., T.F. Schilling, R.A. BreM iller, and C.B. Kimmel. 1990. Specification of jaw muscle identity in zebrafish: Correlation with engrailed-homeoprotein expression. Science 250: 802805.

Hatta, K., R. Bremiller, M. Westerfield, and C.B. Kimmel. 1991. Diversity of expression of engrailed-like antigens in zebrafish. Development 112: 821-832.

Holland, L.Z., D.A. Pace, M.L. Blink, M. Kene, and N.D. Holland. 1995. Sequence and expression of amphioxus alkali myosin light chain (AmphiMLC-alk) throughout development: Implications for vertebrate myogenesis. Dev. Biol. 171: 665-676.

Huang, Z. and S. Kunes. 1996. Hedgehog, transmitted along retinal axons, triggers neurogenesis in the developing visual centers of the Drosophila brain. Cell 86: 411-422.

Hughes, S.M. and H.M. Blau. 1992. Muscle fiber pattern is independent of cell lineage in postnatal rodent development. Cell 68: 659-671.

Hughes, S.M., M. Cho, I. Karsch-Mizrachi, M. Travis, L. Silberstein, L.A. Leinwand, and H.M. Blau. 1993. Three slow myosin heavy chains sequentially expressed in devel oping mammalian skeletal muscle. Dev. Biol. 158: 183-199.

Johnson, R.L., E. Laufer, R.D. Riddle, and C. Tabin. 1994. Ectopic expression of Sonic hedgehog alters dorsal-ventral patterning of somites. Cell 79: 1165-1173.

Kelly, A.M. and N.A. Rubinstein. 1980. Why are fetal muscles slow? Nature 288: 266-269.

Kenny-M obbs, T. and P. Thorogood. 1987. Autonomy of differentiation in avian brachial somites and the influence of adjacent tissues. Development 100: 449-462.

Kimmel, C.B. and R.M. Warga. 1987. Cell lineages generating axial muscle in the zebrafish embryo. Nature 327: 234-237.

Krauss, S., J.-P. Concordet, and P.W. Ingham. 1993. A functionally conserved homologue of the Drosophila segment polarity gene hh is expressed in tissues with polarizing activity in zebrafish embryos. Cell 75: 1431-1444.

Lassar, A.B. and A.E. M unsterberg. 1996. The role of positive and negative signals in somite patterning. Curr. O pin. Neurobiol. 6: 57-63.

Lin-Jones, J. and S.D. Hauschka. 1996. M yogenic determination factor expression in the developing avian limb bud: An RTPCR analysis. Dev. Biol 174: 407-422.

Marigo, V. and C.J. Tabin. 1996. Regulation of patched by sonic hedgehog in the developing neural tube. Proc. Natl. Acad. Sci. 93: 9346-9351.

Maroto, M., R. Reshef, A.E. M ünsterberg, S. Koester, M. Goulding, and A.B. Lassar. 1997. Ectopic Pax-3 activates MyoD and Myf-5 expression in embryonic mesoderm and neural tissue. Cell 89: 139-148.

Marti, E., R. Takada, D.A. Bumcrot, H. Sasaki, and A.P. M cMahon. 1995. Distribution of Sonic hedgehog peptides in the developing chick and mouse embryo. Development 121: 2537-2547.

Miller, J.B. and F.E. Stockdale. 1986. Developmental origins of skel etal muscle fibres: Clonal analysis of myogenic cell lineages based on expression of fast and slow myosin heavy chains. Proc. Natl. Acad. Sci. 83: 3860-3864.

Morin-Kensicki, E.M. and J.S. Eisen. 1997. Sclerotome development and peripheral nervous system segmentation in em- bryonic zebrafish. Development 124: 159-167.

M unsterberg, A.E., J. Kitajewski, D.A. Bumcrot, A.P. M cM ahon, and A.B. Lassar. 1995. Combinatorial signaling by sonic hedgehog and Wnt family members induces myogenic bHLH gene expression in the somite. Genes \& Dev. 9: 2911-2922.

Odenthal, J., P. Haffter, E. Vogelsang, M. Brand, F.J.M. Van Eeden, M. Furutani-Seiki, M. Granato, M. Hammerschmidt, C.P. Heisenberg, Y.J. Jiang, D.A. Kane, R.N. Kelsh, M.C. Mullins, R.M. Warga, M.L. Allende, E.S. Weinberg, and C. $\mathrm{N}$ üsslein-Volhard. 1996. Mutations affecting the formation of the notochord in the zebrafish, Danio rerio. Development 123: 103-115.

Ott, M.-O., E. Bober, G. Lyons, H. Arnold, and M. Buckingham. 1991. Early expression of the myogenic regulatory gene, myf5 , in precursor cells of skel etal muscle in the mouse embryo. Development 111: 1097-1107.

Page, S., J.B. Miller, J.X. DiM ario, E.J. Hager, A. M oser, and F.E. Stockdale. 1992. Developmentally regulated expression of three sl ow isoforms of myosin heavy chain: Diversity among the first fibers to form in avian muscle. Dev. Biol. 154: 118128.

Pownall, M.E., K.E. Strunk, and C.P. Emerson, Jr. 1996. N otochord signals control the transcriptional cascade of myogenic bHLH genes in somites of quail embryos. Development 122: 1475-1488.

Pourquie, O., M. Coltey, M.-A. Teillet, C. Ordahl, and N.M. Le Douarin. 1993. Control of dorsoventral patterning of somitic derivatives by notochord and floor plate. Proc. Natl. Acad. Sci. 90: 5242-5246.

Pourquie, O., C.-M. Fan, M. Coltey, E. Hirsinger, Y. Watanabe, C. Breant, P. Francis-West, P. Brickell, M. Tessier-Lavigne, and N.M. Le Douarin. 1996. Lateral and axial signals involved in avian somite patterning: A role for BMP4. Cell 84: 461-471.

Quinn, L.S., H. Holtzer, and M. Nameroff. 1985. Generation of chick skeletal muscle cells in groups of 16 from stem cells. Nature 313: 692-694.

Roelink, H., A. Augsburger, J. Heemskerk, V. Korzh, S. N orlin, A. Ruiz i Altaba, Y. Tanabe, M. Placzek, T. Edlund, T.M. Jessell, and J. Dodd. 1994. Floor plate and motor neuron induction by vhh-1, a vertebrate homologue of hedgehog expressed by the notochord. Cell 76: 761-775.

Rong, P.M., A.-M . Teillet, C. Ziller, and N .M. Le Douarin. 1992. The neural tube/notochord complex is necessary for vertebral but not limb and body wall striated muscle differentiation. Development 115: 657-672.

Rudnicki, M.A., P.N.J. Schnegelsberg, R.H. Stead, T. Braun, H.-H. Arnold, and R. Jaenisch. 1993. MyoD or Myf-5 is re quired for the formation of skeletal muscle. Cell 75: 13511359.

Schafer, D.A., J.B. Miller, and F.E. Stockdale. 1987. Cell diversification within the myogenic lineage: In vitro generation of two types of myoblasts from a single myogenic progenitor cell. Cell 48: 659-670.

Schier, A.F., S.C.F. N euhauss, K.A. Helde, W.S. Tal bot, and W. Driever. 1997. The one-eyed pinhead gene functions in mesoderm and endoderm formation in zebrafish and interacts with no tail. Development 124: 327-342.

Schiaffino, S., L. Gorza, S. Sartore, L. Saggin, S. Ausoni, M. Vianello, K. Gundersen, and T. Lomo. 1989. Three myosin heavy chain isoforms in type 2 skeletal muscle fibres. J. Muscle Res. Cell Motil. 10: 197-205.

Schulte-Merker, S., F.J.M. van Eeden, M.E. Halpern, C.B. Kimmel, and C. N usslein-Volhard. 1994. no tail (ntl) is the zebrafish homologue of the mouse T (Brachyury) gene. Development 120: 1009-1015. 
Solnica-Krezel, L., D.L. Stemple, E. Mountcastle-Shah, Z. Rangini, S.C.F. Neuhauss, J. Malicki, A.F. Schier, D.Y.R. Stainier, F. Zwartkruis, S. Abdelilah, and W. Driever. 1996. Mutations affecting cell fates and cellular rearrangements during gastrulation in zebrafish. Development 123: 67-80.

Stern, H.M. and S.D. Hauschka. 1995. Neural tube and notochord promote in vitro myogenesis in single somite explants. Dev. Biol. 167: 87-103.

Stern, H.M., A.M.C. Brown, and S.D. Hauschka. 1995. M yogenesis in paraxial mesoderm: Preferential induction by dorsal neural tube and by cells expressing Wnt-1. Development 121: $3675-3686$.

Stone, D.M., M. Hynes, M. Armanini, T.A. Swanson, Q. Gu, R.L. Johnson, M.P. Scott, D. Pennica, A. Goddard, H. Phillips, M. N oll, J.E. Hooper, F. De Sauvage, and A. Rosenthal. 1996. The tumour-suppressor gene patched encodes a candidate receptor for Sonic hedgehog. Nature 384: 129-134.

Tajbakhsh, S., D. Rocancourt, G. Cossu, and M. Buckingham. 1997. Redefining the genetic hierarchies controlling skel etal myogenesis: Pax-3 and Myf-5 act upstream of MyoD. Cell 89: 127-138.

Tal bot, W.B., B. Trevarrow, M.E. Hal pern, A.E. M elby, G. Farr, T.J. Postlethwait, C.B. Kimmel, and D. Kimmel man. 1995. A homeobox gene essential for zebrafish notochord development. Nature 378: 150-157.

Teillet, M.-A. and N.M. Le Douarin. 1983. Consequences of neural tube and notochord excision on the development of the peripheral nervous system in chick embryos. Dev. Biol. 98: 192-211.

Ticho, B.S., D.Y.R. Stainier, and M.C. Fishman. 1996. Three zebrafish MEF2 genes delineate somitic and cardiac muscle development in wild-type and mutant embryos. Mech. Dev. 59: 205-218.

van Eeden, F.J.M., M. Granato, U. Schach, M. Brand, M. Furutani-Seiki, P. Haffter, M. Hammerschmidt, C.P. Heisenberg, Y.-J. Jiang, D.A. Kane, R.N. Kelsh, M.C. Mullins, J. Odenthal, R.M. Warga, M.L. Allende, E.S. Weinberg, and C. N üsslein-Volhard. 1996. Mutations affecting somite formation and patterning in the zebrafish, Danio rerio. Development 123: 153-164.

van Raamsdonk, W., C.W. Pool, and G. te Kronnie. 1978. Differentiation of muscle fibre types in the teleost Brachydanio rerio. Anat. Embryol. 153: 137-155.

Vivarelli, E., W.E. Brown, R.G. Whalen, and G. Cossu. 1988. The expression of slow myosin during mammalian somitogenesis and limb bud differentiation. J. Cell Biol. 107:21912197.

Vortkamp, A., K. Lee, B. Lanske, G.V. Segre, H.M. Kronenberg, and C.J. Tabin. 1996. Regulation of rate of cartilage differentiation by Indian Hedgehog and PTH-related protein. Science 273: 613-622.

Webster, C., L. Sil berstein, A.P. Hays, and H.M. Blau. 1988. Fast muscle fibers are preferentially affected in Duchenne muscular dystrophy. Cell 52: 503-513.

Weinberg, E.S., M.L. Allende, C.S. Kelly, A. Abdelhamid, T. Murakami, P. Andermann, O.G. Doerre, D.J. Grunwald, and B. Riggleman. 1996. Developmental regulation of zebrafish $M y o D$ in wild-type, no tail, and spadetail embryos. Development 122: 271-280.

Westerfield, M. 1995. The zebrafish book. University of Oregon Press. Eugene, OR. 


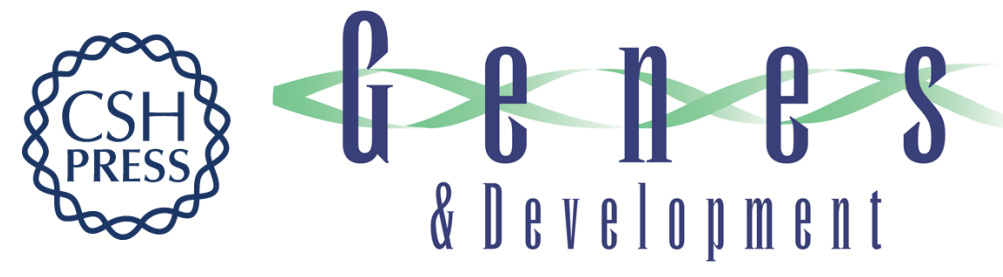

\section{Notochord induction of zebrafish slow muscle mediated by Sonic hedgehog}

Chris S. Blagden, Peter D. Currie, Philip W. Ingham, et al.

Genes Dev. 1997, 11:

Access the most recent version at doi:10.1101/gad.11.17.2163

References

This article cites 76 articles, 33 of which can be accessed free at: http://genesdev.cshlp.org/content/11/17/2163.full.html\#ref-list-1

\section{License}

Email Alerting Service
Receive free email alerts when new articles cite this article - sign up in the box at the top right corner of the article or click here.

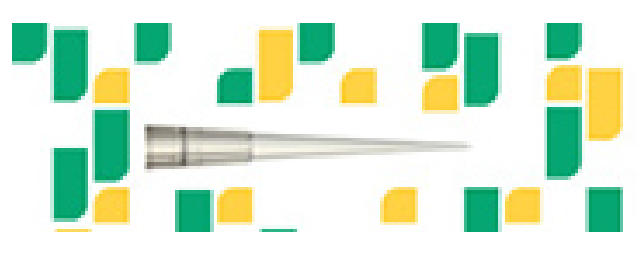

Focused on your science. 